\title{
SUPLIKA JÓZEFA WESZELA DYREKTORA ARCHIWUM I BIBLIOTEKI W NIEŚWIEŻU SKIEROWANA DO MICHAŁA KAZIMIERZA RADZIWIŁŁA ZW. „RYBEŃKO”
}

\section{Słowa kluczowe}

Józef Weszel; archiwa magnackie w Polsce; archiwum i biblioteka w Nieświeżu; archiwum nieświeskie Radziwiłłów; archiwiści nieświescy; archiwiści magnaccy

\section{Keywords}

Józef Weszel; noble family archives in Poland; archives and library in Nieśwież; archives of the Radzwiłł family in Nieśwież; archivists of Nieśwież; archivist of noble families

\section{Streszczenie}

Artykuł opisuje trudności i niedogodności w pracy w archiwum magnackim z jakimi spotykali się archiwiści zatrudnieni w nieświeskim archiwum Radziwiłłów w I poł. XVIII w. O tym jak wyglądały jasne i ciemne strony pracy nieświeskich archiwistów zatrudnionych u Michała Kazimierza Radziwiłła zw. „Rybeńko” (1702-1762), wojewody

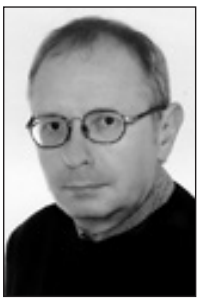

Rafał Jankowski, absolwent studiów historycznych o specjalności archiwistycznej na Uniwersytetu Mikołaja Kopernika w Toruniu. Długoletni pracownik Archiwum Głównego Akt Dawnych w Warszawie, obecnie zatrudniony tam na stanowisku starszego kustosza. Specjalista w zakresie historii, organizacji oraz zasobu archiwów magnackich i szlacheckich, głównie z terytorium Wielkiego księstwa Litewskiego. Tej problematyce poświęcony jest w zasadzie cały jego dorobek naukowy. E-mail: rjankowski@archiwa.gov.pl 
wileńskiego i hetmana wielkiego litewskiego najwięcej informacji przekazuje głównie ich korespondencja. Podsumowaniem tych wszystkich bolączek z jakimi spotykali się tamtejsi archiwiści była sześciopunktowa suplika z 23 X 1743 roku dyrektor biblioteki i archiwum w Nieświeżu Józef Weszel skierowana do pracodawcy, która została wydana jako aneks do powyższego artykułu.

(0) statnimi laty ukazała się monografia Krzysztofa Syty Archiwa magnackie w XVIII wieku. Studium kultury kancelaryjno-archiwalnej, gdzie autor opracowania powstrzymał się od gruntownego przebadania archiwów Radziwiłłów. Według niego stanowią one temat sam w sobie i zasługują na odrębną monografię ${ }^{1}$. Jeden z wątków wspomnianej pracy poświęcony został zadaniom, jakie wykonywały osoby odpowiedzialne za organizację i funkcjonowanie magnackich archiwów oraz warunkom ich pracy. W tym zakresie archiwalia z zasobów radziwiłłowskich archiwów przynoszą wiele ciekawych informacji, które uzupełniają dotychczasowy stan wiedzy.

Poniżej opisane zostaną trudności i niedogodności w pracy w archiwum magnackim, z jakimi spotykali się archiwiści zatrudnieni w nieświeskim archiwum Radziwiłłów w XVIII w.. Artykuł z założenia nie ma nam przedstawić zalet i korzyści wynikających ze służby na rzecz magnata, bo te wydają się oczywiste: uposażenie - nie we wszystkich wypadkach jak zobaczymy niżej, możliwość awansu społecznego, kariera urzędniczo-polityczna, objęcie patronatem, powiększenie majątku w postaci lukratywnych dzierżaw, darowizn itp. lub w skrajnych wypadkach podreperowanie upadającego. Zaletą pracy w archiwum magnackim mogła być również prawie że nieograniczona możliwość dostępu do zgromadzonych tam archiwaliów. Informacje w nich zawarte były wykorzystywane oczywiście głównie w celach pragmatycznych. Jednak niektórzy magnaccy archiwiści wykorzystywali je również jako źródła do realizacji swoich ambicji naukowych ${ }^{2}$.

Dużo ciekawsze są natomiast z punktu widzenia archiwoznawczego wady bycia magnackim archiwistą. Powyższy tekst pokaże, że niejednokrotnie przyszło

${ }^{1}$ K. Syta, Archiwa magnackie $w$ XVIII wieku. Studium kultury kancelaryjno-archiwalnej, Toruń 2010, s. 30.

${ }^{2}$ Do zalet w służbie u Radziwiłłów w połowie XVIII w. niewątpliwie należy zaliczyć bliski i częsty kontakt z magnatem, może też to, że na starość większość dyrektorów archiwum i biblioteki w Nieświeżu dostawało w dzierżawę lub dożywocie folwark. W opisywanym okresie żaden z archiwistów i bibliotekarzy w Nieświeżu nie przejawiał ambicji literackich ani zamiłowań historycznych, tak jak to miało miejsce w XVII i XIX w. 
archiwistom magnackim pracować o głodzie i w chłodzie. Artykuł ma charakter przyczynkarski do dziejów archiwum nieświeskiego Radziwiłłów w I poł. XVIII w., a ściślej ogranicza się do okresu, gdy faktycznym ordynatem nieświeskim i ołyckim był Michał Kazimierz Radziwiłł zw. „Rybeńko” (1702-1762), wojewoda wileński i hetman wielki litewski, czyli od ok. 1735-1736 r., gdy doszło do podziału majątku i archiwum $^{3} \mathrm{z}$ bratem podczaszym i chorążym wielkim litewskim Hieronimem Florianem Radziwiłłem (1715-1760), aż do jego śmierci w 1762 r. ${ }^{4}$ Jest to okres, gdy zamek w Nieświeżu był już odbudowany po zniszczeniach dokonanych przez wojska szwedzkie w czasie wojny północnej, a co za tym idzie w miarę uporządkowane było tamtejsze archiwum. Ten niedługi, jak na dzieje archiwum nieświeskiego, czas stabilizacji skończył się wkrótce po śmierci „Rybeńki”, przynosząc kolejny etap ciągłych przemieszczeń archiwaliów nieświeskich z miejsca na miejsce w czasach samodzielnych rządów syna „Rybeńki”, Karola Stanisława Radziwiłła zw. „Panie Kochanku” (1734-1790) sprawującego po ojcu urząd wojewody wileńskiego 5 .

Syta w monografii wśród różnorodnych zadań wykonywanych przez osoby zajmujące się magnackimi archiwami w XVIII w. wymienia z tych najuciążliwszych kwerendy. Były one wykonywane masowo zarówno w lawinowo narastającym zasobie archiwów prywatnych, jak i z konieczności, w księgach urzędowych. Te drugie miały na celu odbudowanie, co prawda tylko w postaci urzędowych ekstraktów, ewentualnie niepotwierdzonych kopii, strat w zasobach archiwów prywatnych spowodowanych głównie działaniami wojennymi II poł. XVII w. W podrozdziale „kwerendziści” wspomniano o sygnalizowanych przez magnackich oficjalistów niewygodach $\mathrm{w}$ trakcie prowadzonych przez nich kwerend oraz braku zainteresowania tym zajęciem wśród palestry kancelarii grodzkich i ziemskich. W kolejnym rozdziale omawiającym procesy archiwizacyjne w archiwach magnackich w XVIII w., wspomniane jest, że pracownicy archiwów narzekali na nadmiar pracy i braki wystarczającej liczby pomocników w prowadzeniu prac porządkowo-inwentaryzacyjnych i na ogólny „bałagan” w archiwach, szczególnie tych magnackich. W kolejnym rozdziale, poświęconym

${ }^{3}$ R. Jankowski, Archiwum Radziwiłłów w Białej około 1736 roku, „Miscellanea Historico-Archivistica", t. 23, 2016, s. 210-211, 215-216, 218-221.

4 Zob. bliżej: H. Dymnicka-Wołoszyńska, Radziwiłt Michał Kazimierz zwany Rybeńko h. Trąby, [w:] Polski słownik biograficzny (dalej PSB), t. 30, red. E. Rostworowski, Wrocław 1987, s. 299-306; taż, Radziwiłł Hieronim Florian h. Trąby, [w:] PSB, t. 30, red. E. Rostworowski, Wrocław 1987, s. 185-188.

5 J. Michalski, Radziwiłt Karol Stanistaw zwany Panie Kochanku h. Traby, [w:] PSB, t. 30, red. E. Rostworowski, Wrocław 1987, s. 248-262. 
magnackim archiwistom, jest mowa o zaległościach w ich terminowym uposażaniu, o które niejednokrotnie toczono batalie sądowe. Wydaje się, że zaległości płacowe na osiemnastowiecznych dworach magnackich były standardem ${ }^{6}$, który dotykał wszystkich bez wyjątku urzędników. Syta w jednym z artykułów, również zwrócił uwagę na problemy z odczytem dokumentów pisanych cyrylicą przez archiwistów w Koronie w XVIII w. ${ }^{7}$ Nie inaczej było w Wielkim Księstwie Litewskim, gdzie formalnie językiem urzędowym był ruski do końca XVII w. Wśród elit litewsko-ruskich już jednak od poł. XVII w. zauważa się słabą znajomość tego języka, stąd z pewnością w poł. XVIII w. akta w tym języku sprawiały dużą trudność urzędnikom zatrudnionym w archiwach magnackich.

O tym jak wyglądały jasne i ciemne strony pracy nieświeskich archiwistów w I poł. XVIII w. najwięcej informacji przekazuje głównie ich korespondencja. Wynika z niej, że rzeczywisty czas spędzony na pracach ściśle archiwalnych był dość ograniczony. Rewizja zasobu archiwalnego, połączona z pracami porządkowymi i licznymi kwerendami były podstawowymi zajęciami osób odpowiedzialnych za porządek i zabezpieczenie zasobów magnackich archiwów. Poza tym wykonywały one rozmaite funkcje wynikające z potrzeby chwili na dworze magnata, często łącząc je ze sprawowaniem funkcji publicznych. Część z tych zajęć była stałym dodatkiem, inne wykonywali tylko czasowo. W Nieświeżu od połowy XVII w. (od czasów dyrektorstwa Jana Hanowicza) było tradycją łączenie funkcji archiwisty i bibliotekarza ${ }^{8}$. Z częstych, dodatkowych zajęć osób, pod nadzorem których było archiwum, pojawiają się obowiązki sekretarza, tłumacza, plenipotenta, rewizora czy kuriera magnackiego do specjalnych zadań wymagających zaufania, taktu i dyskrecji ${ }^{9}$. Jednym z takich archiwistów,

${ }^{6}$ K. Syta, dz. cyt., s. 86, 101-103, 223, 226; tenże, Jan Józef Witoszyński-archiwista Sieniawskich i Czartoryskich z XVIII wieku. Przyczynek do dziejów archiwistyki prywatnej okresu staropolskiego, „Archiwista Polski”, nr 2, 2002, s. 26-28.

7 Tenże, Jan Józef Witoszyński, s. 28.

8 Jan Hanowicz archiwista i bibliotekarz u ordynata nieświeskiego Aleksandra Ludwika Radziwiłła (1594-1654), marsz. ndw. lit., woj. brzeskiego; R. Jankowski, Archiwiści i instrukcje archiwalne napisane dla nich $w$ Archiwum Głównym Radziwiłtów w Nieświeżu, „Archiwista Polski”, nr 2, 2000, s. 35-37; tenże, Rękopisy i archiwalia $w$ bibliotece $w$ Nieświeżu do połowy XVIII wieku. Zarys problematyki, [w:] Historia. Memoria. Scriptum. Księga jubileuszowa z okazji osiemdziesięciolecia urodzin Profesora Edwarda Potkowskiego, red. J. Krochmal, Warszawa 2015, s. 115.

9 K. Syta, Archiwa magnackie, s. 218-224, 227-228; tenże, Jan Józef Witoszyński, s. 25-35; zob., też treść korespondencje archiwistów radziwiłłowskich z omawianego okresu Aleksandra Goffauxa z lat 1734-1763, Archiwum Główne Akt Dawnych w Warszawie (dalej AGAD), Archiwum Warszawskie Radziwiłłów (dalej AR) dz. V, sygn. 4388, s. 1-210; Antoniego Kałakuckiego z lat 1756-1782, tamże, sygn. 6292, s. 1-44; Józefa 
obarczonym licznymi dodatkowymi obowiązkami, był Aleksander Goffaux, który poza dyrektorstwem nad archiwum w Białej w latach 1744-1746, pełnił też funkcje jednocześnie lub czasowo, od 1721 r. archiwisty i bibliotekarza, kapitana garnizonu słuckiego, komendanta zamku bialskiego, architekta, inżyniera i na koniec kariery sekretarza do języka francuskiego u Hieronima Floriana Radziwiłła ${ }^{10}$.

Wśród źródeł archiwalnych w zasobie Warszawskiego Archiwum Radziwiłłów występuje wiele, które w znaczny sposób wzbogacają naszą wiedzę na temat zakresu i warunków pracy magnackich archiwistów. Wśród nich za wyjątkowe uznać należy listy i suplikę Józefa Weszela dyrektora archiwum i biblioteki Radziwiłłów w Nieświeżu zatrudnionego na usługach Michała Kazimierza Radziwiłła zw. „Rybeńko”. Nie wspomina o nich Andrzej Łatuszkin w swoim doktoracie poświęconym dziejom archiwum nieświeskiego od II poł. XVIII do I poł. XX w. ${ }^{11}$ Inne opracowania dotyczące archiwum w Nieświeżu nie poruszają tematu warunków pracy archiwistów nieświeskich nawet marginalnie ${ }^{12}$, z wyjątkiem Rafała Jankowskiego ${ }^{13}$.

W poł. XVIII w. archiwum i biblioteka w Nieświeżu były nierozdzielone organizacyjnie i zajmowały dwa długie sklepione pomieszczenia w skrzydłach bramnych (odchodzących od bramy wjazdowej na zamek), doświetlone siedmioma oknami od strony dziedzińca. Od północy znajdowało się archiwum, a od zachodu biblioteka ${ }^{14}$. Dyrektorem tej instytucji w latach 1739-1755 (na służbie u Radziwiłłów od ok. 1735 r.) był wymieniony już wcześniej Józef Weszel (vel Wetzela) ${ }^{15}$, syn Michała Weszela, też dyrektora archiwów, ale bialskich

Weszela z lat 1739-1782, tamże, sygn. 17177, s. 1-262 i ojca poprzedniego Michała Weszela z lat 1731-1744, tamże, sygn. 17192, s. 1-52.

${ }^{10}$ R. Jankowski, Archiwum, s. 210-212.

${ }^{11}$ A. M. Latuškìn, Nâsvǐžskì arhìu knâzëǔ Radzìvìlaǔ u kancu XVIII - peršaj palove XX stst., Mìnsk 2007.

${ }^{12}$ Bibliografię najważniejszych prac dotyczących archiwum zob.: R. Jankowski, Opis archiwum nieświeskiego z 1857 roku, „Miscellanea Historico-Archivistica”, t. 21, 2014, s. 313-315 (przyp. nr 27-29).

${ }^{13}$ Tenże, Burzliwe losy archiwum Radziwiłtów w Nieświeżu od XV w. do 1838 r., „Miscellanea Historico-Archivistica", t. 11, 2000, s. 40-41; tenże, Prace inwentaryzacyjne w Archiwum Głównym Radziwiłtów w Nieświeżu do 1945 r., „Archiwista Polski”, nr 3, 2000, s. 44-45, 54.

14 T. Bernatowicz, Mitra i buława. Królewskie ambicje książąt w sztuce Rzeczypospolitej szlacheckiej (1697-1763), Warszawa 2011, s. 331.

15 AGAD, AR dz. V, sygn. 17177, s. 225, Wetzel do K. S. Radziwiłła zw. „Panie Kochanku", z Dubiejek 30 VI 1775 r. 
u matki „Rybeńki” kanclerzyny Anny Katarzyny z Sanguszków Radziwiłłowej (1676-1746) ${ }^{16}$ w latach 1725-1744. Karierę Weszela na dworze Radziwiłłów przerwało aresztowanie z powodu nieprawidłowości w administracji manufaktury sukienniczej w Nieświeżu, gdzie jednocześnie z funkcją dyrektora - archiwisty i bibliotekarza piastował posadę superintendenta. Po roku Weszel wrócił do służby u „Rybeńki”, jednak dyrektorstwa nad archiwum i biblioteką nie odzyskał ${ }^{17}$. Od października 1755 r. nad archiwum i biblioteką w Nieświeżu pieczę dzierżył Antoni Kałakucki ${ }^{18}$.

Jak wynika z listów Józefa Weszela kierowanych do Michała Kazimierza Radziwiłła w okresie jego dyrektorowania nieświeskim archiwum i biblioteką, zwracał on uwagę na różne problemy pojawiające się w trakcie wykonywania przez niego obowiązków archiwisty. Dotyczyły one zarówno pracy w archiwum w Nieświeżu, ale również i podległej mu sieci radziwiłłowskich archiwów. Jednym z poważniejszych problemów w pracy Weszela była niechęć administracji radziwiłłowskiej do współpracy z archiwistą w zakresie inwentaryzowania zasobu archiwum. Zauważał w liście: „nieświ[e]skie inwentarze, czyli mam kontynuować, czyli też ni, ale potrzebuję uniwersału, bo posłuszeństwa nie będzie"19. Dalej w tym samym tekście skarżył się na nieporządek oraz brak wystarczającej liczby personelu do skali stawianych zadań, pisząc „archiwami się bawię, gdzie takie chaos znalazłem, iż do Zielonych Świątek liedwie co nadrobię, lecz jednym [Antonim] Hlebko trudno się obejść, potrzeba koniecznie drugiego, gdyż jest co do czynienia, próżnować sumienie moje w tym, że nie będą"20.

Z korespondencji Wszela wynika, że nieporządek w papierach powstawał w trakcie każdej dłuższej nieobecności archiwisty: „Sam tym czasem w niebytności mojej w archiwach tak wielkę chaos koło porządku, bawię się"21.

${ }^{16}$ Zob. bliżej: W. Karkucińska, Anna z Sanguszków Radziwiłłowa (1676-1746). Działalność gospodarcza i mecenat, Warszawa 2000; taż, Radziwiłłowa z Sanguszków Anna Katarzyna, [w:] PSB, t. 30, red. E. Rostworowski, Wrocław 1987, s. 384-387.

17 AGAD, AR dz. V, sygn. 17177, s. 176, Weszel do M. K. Radziwiłła zw. „Rybeńko”, Nieśwież 11 V 1759 r. oraz listy z lat 1758-1782, s. 172-262; R. Jankowski, Archiwiści, s. 36.

${ }^{18}$ Podział kompetencji poszczególnych dworzan radziwiłłowskich w poł. XVIII w. nie jest do końca znany. Te same osoby mogły być jednocześnie na usługach woj. wileńskiego i h. w. lit. Michała Kazimierza Radziwiłła zw. „Rybeńko” (1702-1762) w Nieświeżu, Ołyce i Żółkwi, jego brata chor. w. lit. Hieronima Floriana (1715-1760) w Mirze i Słucku oraz ich matki kanclerzyny Anny Katarzyny z Sanguszków Radziwiłłowej (1676-1746) w Białej; R. Jankowski, Archiwiści, s. 35-36; tenże, Archiwum, s. 213.

${ }^{19}$ AGAD, AR dz. V, nr 17177, s. 22, Weszel do M. K. Radziwiłła zw. „Rybeńko”, Nieśwież 15 IV $1741 \mathrm{r}$.

${ }^{20}$ Tamże, s. 22-23.

${ }^{21}$ Tamże, s. 59, tenże do tegoż, Nieśwież 25 IX 1743 r. 
Prawdziwe wyzwanie spotkało Weszela dopiero po przejęciu przez Michała Kazimierza Radziwiłła części archiwów Sobieskich w następstwie transakcji z 1738 r. Przybywając do Żółkwi, gdzie znajdowała się większość przejętych wówczas archiwaliów, zastał totalny bałagan, co przedstawił Radziwiłłowi w następujących słowach: „miałem klucz, ale nie wiem o żadnych papierach, gdyż nie mam ani żadnego regestru, ani sumariuszu, a co większa, że wielkie zamieszanie w papierach, dość, że nie wiem jakie papiery są, a jakich nie masz"22.

W innym liście pisanym z Żółkwi dyrektor archiwum i biblioteki w Nieświeżu ponownie skarżył się na brak rąk do pracy („od nikogo żadnej pomocy”23) i drożyznę poza stałym miejscem zamieszkania: „Czekam oraz już tak długi czas na [Antoniego] Hlebkę, którego doczekać się nie mogę, a jeżeli dłużej siedzieć w Żółkwi przyjdzie Bóg mój widzi, że sposobu do życia tu cudzym mieście, mieć nie będę przy takiej drożynie, jednak nic na to nie dbam, abym tylko przy osobliwszej łasce WKsMci"24.

Z listów Weszela wynika, że praca archiwisty, a zwłaszcza dyrektora archiwów radziwiłłowskich wymagała dużej mobilności i z pewnością liczne wyjazdy z Nieświeża mocno nadszarpywały jego budżet. Było to tym bardziej bolesne, że honoraria, jak wynika ze źródeł, były na ogół na dworze Radziwiłłów w poł. XVIII w. niezbyt wysokie ${ }^{25}$ : „tedy dalej być nie chce, dla małej pensyi, na którą się nie godził, i jego utrzymać nie można, gdyż jest człowiek sobie libere gentis"26.

Jakby podsumowaniem tych wszystkich bolączek z jakimi spotykał się dyrektor Weszel była sześciopunktowa suplika skierowana do pracodawcy Michała Kazimierza Radziwiłła zw. „Rybeńko” z 23 X 1743 r., w której przedstawił swoje postulaty, „żeby archiwa i biblioteka [w Nieświeżu] w dobrym była porządku”27.

W pierwszym punkcie supliki postulował zwiększenie dostaw papieru przeznaczonego do spisywania rejestrów, jak i do oprawy ksiąg i rękopisów. Postulat był nadal aktualny jeszcze w 1745 r., gdyż w jednym z listów dyrektor zgłaszał

22 Tamże, s. 80, tenże do tegoż, Żółkiew 20 IX 1740 r.

${ }^{23}$ Tamże, s. 42, tenże do tegoż, Żółkiew 2 V 1742 r.

${ }^{24}$ Tamże, s. 37, tenże do tegoż, Żółkiew 23 V 1742 r. Na pomoc A. Hlebki czekał Weszel w Żółkwi od co najmniej 2 V 1742 r., tamże, s. 38, tenże do tegoż, Żółkiew 2 V 1742 r.; tamże, s. 86: „staram tylko archiwum do jak doskonalszego przyprowadzić porządku, tylko, że wcale nie mam z kim, ponieważ u mnie tylko jeden Nowosielski, a tak praca wielka", tenże do tegoż, Nieśwież 5 IX 1749 r.

${ }^{25}$ R. Jankowski, Archiwum, s. 213.

${ }^{26}$ AGAD, AR dz. V, nr 17177, s. 10, Weszel do M. K. Radziwiłła zw. „Rybeńko”, Żółkiew 10 IX 1740 r.

27 Tamże, s. 60, tenże do tegoż, Nieśwież 23 X 1743 r. 
podobne postulaty, na co „Rybeńko” na marginesie pisma tylko dopisał: „staraj się pilnować archiwów"28.

Radziwiłł w tym miejscu nie zdobył się nawet na próbę czy sugestię rozwiązania problemów z brakiem wystarczającej ilości papieru. W punkcie drugim Weszel prosił Radziwiłła o regularne opłacanie introligatora będącego na usługach archiwum i biblioteki na bieżąco za każdą obłożoną książkę w bibliotece. W kolejnym punkcie postulował, aby „pisarze archiwowi”, tak jak u matki pracodawcy, Anny Katarzyny z Sanguszków Radziwiłłowej, w archiwum Białej, „brali barwę dla honoru [księcia,] żeby onych przyodziać, bo jak goście przyjadą, że wstydem archiwów będzie mówić [...], bo wcale gołe, że wstyd i mówić"29.

Pieniądze na porządny ubiór dla personelu zdaniem Weszela mogłyby zachęcić urzędników archiwalnych do poczciwości, co jednocześnie może w przyszłości zapobiec „inkwizycji”30, która przytrafiła się jednemu z nich. Funkcja archiwisty była „przysięgą obowiązana”31, a niewywiązanie się z niej, pociągało postawienie delikwenta przed sąd książęcy. W kolejnym punkcie supliki dyrektor skarżył się na brak ogrzewania pomieszczeń archiwalnych, co było dużą uciążliwością w trakcie wykonywania obowiązków. W piątym punkcie supliki Weszel informował Radziwiłła, że od pół roku nie otrzymywał wynagrodzenia za swoją służbę. W ostatnim, szóstym punkcie Weszel, niejako przy okazji, załatwiał jedną ze swoich urzędowych spraw. Padając „pod stopy” Radziwiłłowi zgodnie z obowiązującą etykietą kończył suplikę nazywając siebie „najniższym podnóżkiem”32.

Brak adnotacji Michała Kazimierza Radziwiłła „Rybeńki” na tekście supliki, ani jego dyspozycji wyrażonej ręką sekretarza sugeruje, że postulaty przeszły bez echa. Dla ścisłości dodam, że raczej nie należało się tego spodziewać, aby było inaczej, gdyż załatwienie postulatów tego rodzaju dla takiego magnata jakim był „Rybeńko” było sprawą marginalną. Poniekąd pogląd ten potwierdza fakt, że w diariuszu Radziwiłła w zapiskach z października i listopada 1743 r. brak jakichkolwiek odnośników do prośby Weszela, poza ogólnymi sformułowaniami, które bardzo często występują w tekście: „pocztę odebrałem i ekspediowałem”33.

${ }^{28}$ Tamże, s. 68-69, tenże do tegoż, Nieśwież 7 XI 1745 r.

29 Tamże, s. 61, tenże do tegoż, Nieśwież 23 X 1743 r.

30 Tamże, dz. XXI, sygn. M 8, s. 1-3, 29 VII 1745 r. Elian Ogonowicz został przesłuchany na okoliczność sprzeniewierzenia się obowiązkom archiwisty.

${ }^{31}$ Tamże, dz. V, sygn. 17177, s. 122, Weszel do M. K. Radziwiłła zw. „Rybeńko”, Nieśwież 8 III 1753 r.; zob. przysięgę archiwisty nieświeskiego z czasów M. K. Radziwiłła zw. „Rybeńko”, R. Jankowski, Archiwiści, s. 38-39; tenże, Archiwum, s. 212.

32 AGAD, AR dz. V, sygn. 17177, s. 60-62, Weszel do M. K. Radziwiłła zw. „Rybeńko”, Nieśwież 23 X 1743 r.

33 Tamże, dz. VI, sygn. II-80 a, s. 1274-1280 (zapiski 23 X - 30 XI 1743 r.). 
W zachowanej korespondencji brak również z tego okresu listu Radziwiłła $\mathrm{w}$ oryginale lub kopii do dyrektora $\mathrm{z}$ odpowiedzią na powyższe postulaty ${ }^{34}$.

Podsumowując treść listów i supliki autorstwa Weszela, należy stwierdzić, że archiwum nieświeskie Radziwiłłów w I poł. XVIII w. nie odbiegało swoją organizacją od wielu innych archiwów magnackich tej epoki. Problemy o jakich wspominał dyrektor archiwum i biblioteki w Nieświeżu brzmią dość znajomo, i wielu archiwistów prywatnych, nie tylko okresu staropolskiego, musiało się z nimi bardzo często borykać. Po analizie wyżej cytowanej korespondencji ciśnie się jeszcze jedno spostrzeżenie, że generalnie osiemnastowieczne archiwa magnackie nie wyróżniały się wysokim stopniem uporządkowaniem zasobu, stąd do czasów obecnych ich większość nie została należycie opracowana ${ }^{35}$, a wręcz przeciwnie - charakteryzowała się sporym bałaganem ${ }^{36}$. Ze źródeł archiwalnych wynika, że chlubnym wyjątkiem u Radziwiłłów było archiwum w Białej Anny Katarzyny z Sanguszków Radziwiłłowej37, a nie opisywane archiwum w głównej rezydencji Radziwiłłów w Nieświeżu. Wydaje się jednak po analizie inwentarzy i sumariuszy z I poł. XVIII w., że w samym Nieświeżu nie było pod tym względem tak tragicznie ${ }^{38}$ jak w podległej mu sieci archiwów w przejętej Żółkwi, Mirze, Słucku, Warszawie i prawdopodobnie również Ołyce.

\section{Aneks}

Nieśwież, 23 październik 1743 r.

Józef Weszel zwraca się do Michała Kazimierza Radziwiłła zw. „Rybeńko” z postulatami dotyczacymi usprawnienia i polepszenia warunków pracy $w$ archiwum i bibliotece $w$ Nieświeżu.

34 Tamże, dz. IV, sygn. 423, s. 12-27 (29 X-30 XI 1743 r.), nr 867, s. 457-493 (26 X-29 XI 1743 r.) i nr 473-477 (b.d.), M. K. Radziwiłł zw. „Rybeńko” do różnych.

${ }^{35}$ Głównie mam na myśli inwentarze archiwów magnackich i szlacheckich, które znam z autopsji z Litewskiego Państwowego Archiwum Historycznego w Wilnie, fond nr: 459, 598, 599, 716, 1025, 1029, 1039, 1040, 1177, 1195, 1275, 1276, 1278-1281, 1283, 1285, 1292, 1505 i Narodowego Historycznego Archiwum Białorusi w Mińsku, fond nr: 694, 695, 1324, 1503 i 3258.

36 Zob. przykłady: K. Syta, Archiwa magnackie, s. 169-172.

${ }^{37}$ R. Jankowski, Archiwum, s. 214, 218; zob. i por.: K. Syta, Archiwa magnackie, s. 95-98.

38 Zob. AGAD, AR dz. XXVII, sygn. 17 (z 1723 r.), sygn. 18 (z 1724 r.), sygn. 25 (z 1743 r.), sygn. 26 (z 1744 r.), sygn. 27 (z lat 40. XVIII w.), sygn. 29 (z 1755 r.) i tamże, dz. „Rękopisy biblioteczne”, sygn. 164 (z 1741 r.) 
Or.: Archiwum Gtówne Akt Dawnych w Warszawie, tzw. Archiwum Warszawskie Radziwiłtów, dz. V, nr 17177, s. 60-62; język polski; bifolium o wymiarach: $185 \times 225 \mathrm{~mm}$.

Uw. Edycję przygotowano w oparciu o Instrukcję wydawniczą dla źródeł historycznych od XVI w. do poł. XIX w., opr. K. Lepszy, Warszawa 1953. Przy edycji tekstu zrezygnowano z rozwiązywania ogólnie znanych skrótów grzecznościowych,

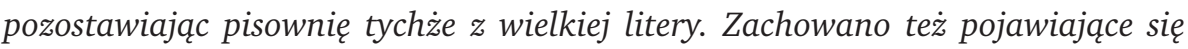
$w$ podstawie wydawniczej podkreślenia. Starano się też oddać charakterystyczne cechy języka, modernizując jednocześnie tekst według wskazań instrukcji wydawniczej.

[s. 60]

Jaśnie Oświecony Mości Książe Panie i Dobrodzieju Miłościwy ${ }^{39}$.

Żeby archiwa i biblioteka w dobrym była porządku i WKsMć Dobrodzi zastał, tak abyśmy żadnej nagany nie mieli, więc o ułatwienie tych punktów suplikuję.

1.

${ }^{a}$ Nie mamy papieru, do pisania kupił nam był Jmć Pan de Konchber ${ }^{40}$ ryzę, która wyszła tak na regestra, jako kopiowania starych przywilejów i dokumentów, proszę do arendarzów tutejszych ordynans aby dodawali, tak papier do pisana jako i do oprawy ksiąg i manuskryptów.

2.

Introligator, ponieważ bardzo zubożał, że chleba nie ma, aby [s. 61] mógł mieć punktualną za każdą sztukę zapłatę, przez co i znaczna w bibliotece będzie reparacja, do tychże arendarzów ordynans.

3.

Pisarze archiwowi, którzy, aby tak jak u matki ${ }^{41}$ WKsMci Dobrodzieja brali barwę dla honoru WKsMci Dobrodzieja, bo wcale gołe, że wstyd i mówić, choćby do

${ }^{39}$ Michał Kazimierz Radziwiłł zw. „Rybeńko” (1702-1762), kaszt. wileński i h. pl. lit., później, woj. wileński i h. w. lit., ordynat nieświeski i ołycki; H. Dymnicka-Wołoszyńska, Radziwiłt Michał Kazimierz zwany Rybeńko h. Trąby, s. 299-306.

${ }^{40}$ Osoba niezidentyfikowana.

${ }^{41}$ Anna Katarzyna z Sanguszków Radziwiłłowa (1676-1746), żona Karola Stanisława Radziwiłła (1669-1719), kanc. w. lit., a matka Michała Kazimierza Radziwiłła zw. „Rybeńko”; W. Karkucińska, Radziwiłłowa z Sanguszków Anna Katarzyna, s. 384-387. 
Icka $^{42}$ asygnację dał z łaski Pańskiej WKsMć Dobrodziej, na pakłak ${ }^{43}$, żeby onych przyodziać, bo jak goście przyjadą, że wstydem archiwów będzie mówić, że archiwistowie, a zwłaszcza nowicjuszowie jeszcze, trzeba onych zachęcić, aby poczciwymi byli.

4.

Aby zimno codziennej nam nie przeszkadzało [w] pracy, suplikuję [s. 62], aby nam dano w zamku, gdzie izbę horodniczy ${ }^{44}$ co dzień kazał palić.

5.

Jankiel arendarz ${ }^{45}$ przeszły pół roku mnie nie zapłacił, a już od Jmci Pana gubernatora kwitowany z całej sumy, więc suplikuję do tych arendarzów o asygnację, aby mnie zapłacili.

6.

List od Pana Dziudziewickiego ${ }^{46}$ do Pana [Jerzego Antoniego] Mikucia ${ }^{47}$ pisany odsyłam tu inkludowany z którego kontentum wyczyta WKsM Pan i Dobrodzi ${ }^{\mathrm{a}}$.

Co wszytko wyraziwszy WKsMci Dobrodziejowi tym kończę, żem jest pod stopy. J.O. Waszej Księżej Mości Pana i Dobrodzieja Miłościwego najniższym podnóżkiem

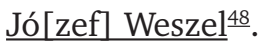

Z Nieświeża ${ }^{49}$

238 -bris ${ }^{50} \underline{1743 .}$.

${ }^{42}$ Osoba niezidentyfikowana.

${ }^{43}$ Stownik języka polskiego, oprac. S. B. Linde, t. II, cz. II: P., Warszawa 1811, s. 610 (h. Pakładowy): „z grubego sukna, parciany”. Pakłak: gruby, najczęściej lniany lub bawełniany materiał.

${ }^{44}$ Zakres obowiązków horodniczego nieświeskiego się zmieniał. W poł. XVIII w. prawdopodobnie należało: czuwaniem nad zamkiem, jego bezpieczeństwem, zarządzaniem kluczami nad skarbcem, czasem archiwum; zob. i por. Stownik, t. I, cz. II: G-L, Warszawa 1808, s. 835 (h. Horodniczowstwo).

45 Osoba bliżej niezidentyfikowana.

${ }^{46}$ Osoba niezidentyfikowana.

47 Jerzy Antoni Mikuć, sekretarz Michała Kazimierza Radziwiłła zw. „Rybeńko”; zob. jego korespondencje z lat 1735-1762, AGAD, AR dz. V, sygn. 9679, s. 1-181, 186-193 oraz finanse tegoż jako superintendenta z lat 1736-1749, tamże, dz. XXI, sygn. M 129.

48 Józef Weszel, dyrektor archiwum i biblioteki w Nieświeżu w latach 1739-1755. Po krótkim uwięzieniu i powrocie do łask zaczął się podpisywać Wetzel; R. Jankowski, Archiwiści, s. 35-36; tenże, Archiwum, s. 213.

${ }^{49}$ Nieśwież, zamek, woj. nowogródzkie.

50 Październik. 
${ }^{\text {a-a }}$ Cały tekst pisany na lewej części karty. Prawa została zostawiona $w$ celu nanoszenia ewentualnych uwag przez Michała Kazimierza Radziwiłła zw. „Rybeńko” lub jego sekretarza.

\section{Archiwalia}

Archiwum Główne Akt Dawnych w Warszawie

- Archiwum Warszawskie Radziwiłłów [1178] 1190-1947

\section{Opracowania}

Bernatowicz T., Mitra i buława. Królewskie ambicje książąt w sztuce Rzeczypospolitej szlacheckiej (1697-1763), Warszawa 2011.

Dymnicka-Wołoszyńska H., Radziwiłt Hieronim Florian h. Trąby, [w:] Polski słownik biograficzny, t. 30, red. E. Rostworowski, Wrocław 1987.

Dymnicka-Wołoszyńska H., Radziwiłł Michał Kazimierz zwany Rybeńko h. Trąby, [w:] Polski słownik biograficzny, t. 30, red. E. Rostworowski, Wrocław 1987.

Instrukcja wydawnicza dla źródeł historycznych od XVI w. do pot. XIX w., opr. K. Lepszy, Warszawa 1953.

Jankowski R., Archiwiści i instrukcje archiwalne napisane dla nich w Archiwum Głównym Radziwiłłów w Nieświeżu, „Archiwista Polski”, nr 2, 2000.

Jankowski R., Archiwum Radziwiłłów w Białej około 1736 roku, „Miscellanea Historico-Archivistica", t. 23, 2016.

Jankowski R., Burzliwe losy archiwum Radziwiłtów w Nieświeżu od XV w. do 1838 r., „Miscellanea Historico-Archivistica”, t. 11, 2000.

Jankowski R., Opis archiwum nieświeskiego z 1857 roku, „Miscellanea Historico-Archivistica", t. 21, 2014.

Jankowski R., Prace inwentaryzacyjne w Archiwum Głównym Radziwiłłów w Nieświeżu do 1945 r., „Archiwista Polski”, nr 3, 2000.

Jankowski R., Rękopisy i archiwalia w bibliotece w Nieświeżu do połowy XVIII wieku. Zarys problematyki, [w:] Historia. Memoria. Scriptum. Księga jubileuszowa z okazji osiemdziesięciolecia urodzin Profesora Edwarda Potkowskiego, red. J. Krochmal, Warszawa 2015.

Karkucińska W., Anna z Sanguszków Radziwiłłowa (1676-1746). Działalność gospodarcza i mecenat, Warszawa 2000.

Karkucińska W., Radziwiłłowa z Sanguszków Anna Katarzyna, [w:] Polski Słownik biograficzny, t. 30, Wrocław 1987.

Latuškìn A. M., Nâsvǐžskì arhìŭ knâzëǔ Radzìvìlaǔ u kancu XVIII - peršaj palove XX stst., Mìnsk 2007.

Michalski J., Radziwiłł Karol Stanisław zwany Panie Kochanku h. Trąby, [w:] Polski słownik biograficzny, t. 30, red. E. Rostworowski, Wrocław 1987.

Słownik języka polskiego, oprac. S. B. Linde, t. I, cz. II: G-L, Warszawa 1808; t. II, cz. II: P, Warszawa 1811. 
Suplika Józefa Weszela dyrektora archiwum i biblioteki w Nieświeżu...

Syta K., Archiwa magnackie w XVIII wieku. Studium kultury kancelaryjno-archiwalnej, Toruń 2010.

Syta K., Jan Józef Witoszyński - archiwista Sieniawskich i Czartoryskich z XVIII wieku. Przyczynek do dziejów archiwistyki prywatnej okresu staropolskiego, „Archiwista Polski", nr 2, 2002.

\section{Summary}

Supplication of Józef Weszel, director of archives and library in Nieśwież, to Michał Kazimierz Radziwiłł alias „Rybeńko”

The article describes difficulties and problem in working in a noble family archives encountered by archivists employed in the archives of the Radzwiłł family in Nieśwież during the first half of the 18th century. Advantages and disadvantages of work of Nieśwież's archivists employed by Michał Kazimierz Radziwiłł alias „Rybeńko” (1702-1762), voivode of Vilnius and Grand Hetman of Lithuania, are described mostly by their correspondence. A summary of these problems was a six-point supplication from October 23, 1743 by the director of archives and library in Nieśwież Józef Weszel, aimed at his employer; the supplication is published as an annex to this article. 